\title{
AN APPRAISAL OF THE APPLICATION OF FIQH $A L$ - HANAFI UNDER ISLAMIC FAMILY LAW (FEDERAL TERRITORIES) ACT 1984
}

\author{
Azizah binti Mohd*
}

\begin{abstract}
Malaysia is a Muslim country consisting of thirteen States and Federal Territories (Kuala Lumpur, Labuan and Putrajaya). In principal, the official madhhab that is practised in Malaysia is Shafi' i Madhhab and this becomes common to all Malaysians even though it is not officially registered in the identification card of a Malaysian. Accordingly, in many religious affairs and practices, the society is based upon the principles or fiqh al-Shafi' $i$. Nevertheless, views of other Sunni madhhab is freely practiced by all Malaysians. Furthermore, the codification on Islamic law in the State Enactments in all States in Malaysia is based upon four Sunni schools of law. It follows that the Islamic law in Malaysia is not purely based on the Shafi'i madhhab and in many occasions adopted the view of Hanafi school depending on the adaptability of the opinion to the society. This article deals with the application of figh al-Hanafi under the Islamic Family Law (Federal Territories) Act 1984. Analysis will extend to the practices in the Malaysian Syariah Court when dealing with cases involving Muslims and the most appropriate view of the madhhab that is to be adopted by the Syariah Court in order to solve a particular issue. The study employs the qualitative method of study where it only involves library research. It is believed that this research will be beneficial to all who seek knowledge and useful to all researchers, academicians, legal practitioners, students and scholars.
\end{abstract}

Keywords: application, Fiqh al-Hanafi, Islamic Family Law, (Federal Territories) Act 1984, Syariah Court

\footnotetext{
Associate Professor at the Department of Islamic Law, Ahmad Ibrahim Kulliyyah of Laws, International Islamic University of Malaysia. Email: azizahmohd@iium.edu.my.
} 


\title{
SATU PENILAIAN BERKAITAN PEMAKAIAN HUKUM FEQAH DALAM MAZHAB HANAFI DI BAWAH AKTA UNDANG-UNDANG KELUARGA ISLAM (WILAYAH- WILAYAH PERSEKUTUAN) 1984
}

\begin{abstract}
ABSTRAK
Malaysia adalah sebuah negara yang mengandungi tiga belas buah negeri dan Wilayah-Wilayah Persekutuan (Kuala Lumpur, Labuan dan Putrajaya). Secara umumnya, rakyat Malaysia bermazhab Shafi'i dan ini telah difahami oleh rakyat Malaysia sejak dulu lagi walaupun bermazhab Shafi'i tidak didaftarkan atau ditulis di dalam mana-mana kad pengenalan. Berikutan dengan itu, masyarakat di Malaysia akan berpandukan kepada prinsip dalam mazhab Shafi'i dalam kebanyakan perkara-perkara dan praktis yang berkaitan dengan agama. Walau bagaimanapun, pandangan dari mazhab-mazhab Sunni yang lain adalah bebas dipraktiskan di Malaysia. Lagipun, pembukuan undang-undang Islam di negeri-negeri adalah berdasarkan kepada empat mazhab sunni. Yang demikian itu juga, undang-undang Islam di Malaysia tidak hanya berdasarkan kepada pandangan dalam mazhab Shafi'i dan dalam banyak kes juga merujuk kepada pandangan dalam mazhab Hanafi bergantung kepada sejauh mana pendapat tersebut boleh diadaptasikan dalam masyarakat. Kertas kerja ini adalah berkaitan dengan pemakaian hukum feqah dalam mazhab Hanafi di dalam Akta Undang-undang Keluarga Islam (Wilayah-Wilayah Persekutuan) 1984. Kertas kerja ini antara lain akan menganalisa amalanamalan di Mahkamah Syariah bila menyelesaikan kes-kes yang melibatkan orang-orang Islam yang memerlukan rujukan kepada pendapat dalam Mazhab Hanafi. Penyelidikan ini adalah bersifat kualitatif yang mana penyelidikan lebih tertumpu kepada penyelidikan di perpustakaan. Amat diyakini bahawa penulisan ini akan memberi manafaat kepada semua yang sedang mencari ilmu, para penyelidik, para akademik, para pelajar dan para ilmuan.
\end{abstract}

Kata Kunci: pemakaian, hukum feqah dalam mazhab Hanafi, undangundang keluarga Islam, Akta Undang-undang Keluarga Islam (Wilayah- Wilayah Persekutuan) 1984, Mahkamah Syariah 


\section{INTRODUCTION}

It is a common practice in Malaysia that the law is divided into civil and Islamic law especially after the introduction of the English law by the Charter of Justice of $1826 .{ }^{1}$ The effect was that, Islamic law was only applied to the Muslims, where the judges felt that it would be unjust or oppressive to apply the English law due to the different habits and customs of the English people and Muslims. ${ }^{2}$ Islamic law has its origin in divine revelation as contained in the holy Quran and the Sunnah of the Prophet (p.b.u.h.), and developed by the opinion of the Muslim jurists. Whereas civil law has its origin in the customs followed in the various parts of England, which were collected and developed into the common law by the judges and later supplemented by legislation. ${ }^{3}$

The power to enact law for the whole Federation is vested upon the Federal government whilst the State can enact law only on State matters. ${ }^{4}$ For example, powers to enact law on matters dealing with Islamic law are

* Part of this article was presented in al-Muktamar al-Duwali al-Hanafiah wa al-Matraediyyah, $5^{\text {th }}$ to $7^{\text {th }}$ May 2017, University of Kastamonu, Turkey. This research is funded by RIGS, International Islamic University Malaysia.

${ }^{1}$ There were three Charters of Justice which introduced English law in the Strait Settlements. The first was granted to Penang in 1807. See Kamoo v Basset (1808) $1 \mathrm{Ky}$; The second was granted to Penang, Singapore and Malacca in 1826 when these three States were incorporated. See In The Goods of Abdullah (1835) 2 Ky.Ecc. 8; The third was in 1855 which reorganized the courts' structure. See Reg. V Williams (1858) 3 Ky. 16. See also Ong Cheng Neo $v$ Yeap Cheah Neo (1872) 1 Ky. 326. See Ahmad Ibrahim and Ahilemah Joned, The Malaysian legal system, 2nd ed. (Kuala Lumpur: Dewan Bahasa dan Pustaka, 1995), 17-20. For details on reception of English Law in Straits Settlement see for examples Michael F. Rutter, The applicable law in Singapore and Malaysia (Singapore: Malaysia: Malayan Law Journal, 1989), 456-458. Ahmad Ibrahim, Towards a history of law in Malaysia and Singapore (Kuala Lumpur: Dewan Bahasa dan Pustaka, 1992), 22-34; Salleh Buang, Malaysian legal history: Cases and materials (Kuala Lumpur: Dewan Bahasa dan Pustaka, 1993), 5-28.

${ }^{2}$ Ahmad Ibrahim, The Administration of Islamic law in Malaysia (Kuala Lumpur: IKIM, 2000), 37.

${ }^{3}$ For further reading see Ahmad Ibrahim, The administration of Islamic law, 37.

${ }^{4}$ See Federal Constitution of Malaysia, part VI, Art. 73. 
entrusted to the State as set out in Federal Constitution in item 1 of the State List. It provides that;

"Except with respect to the Federal Territories of Kuala Lumpur, Labuan and Putrajaya, Islamic law and personal and family law of persons professing the religion of Islam, including Islamic law relating to succession, testate and intestate, betrothal, marriage, divorce, dower, maintenance, adoption, legitimacy, guardianship, gifts, partitions and non-charitable trusts; wakafs and the definition and regulation of charitable and religious trusts, the appointment of trustees and the incorporation of persons in respect of Islamic religious and charitable endowments, institutions, trusts, charities and charitable institutions operating wholly within the State; Malay custom; Zakat, Fitrah and Baitulmal or similar Islamic religious revenue; mosque or any Islamic public place of worship, creation and punishment of offences by persons professing the religion of Islam against precepts of that religion, except in regard to matters included in the Federal List; the constitution, organization and procedure of Syariah Courts which shall have jurisdiction only over persons professing the religion of Islam and in respect only of any of the matters included in this paragraph, but shall not have jurisdiction in respect of offences except in so far as conferred by federal law; the control of propagating doctrines and beliefs among persons professing the religion of Islam; the determination of matters of Islamic law and doctrine and Malay custom." 5

The above provision expressly states that Islamic law shall be dealt with by the State government. It further narrows down the interpretation to include the family and personal law of persons professing the religion of Islam. Therefore, all States in Malaysia have enacted legislation on Islamic family law, which follows the Islamic law based on the Sunni schools of law. ${ }^{6}$ The provisions of the civil law can also be applied to Muslims if it is not contrary to Islamic law. For example, several provisions under the Guardianship of Infants Act $1961^{7}$ have been adopted by several State enactments as they are not contrary to the

\footnotetext{
${ }^{5}$ See List II, State List Ninth Schedule, (Art. 95B) (1) (a).

${ }^{6}$ See for example Islamic Family law (Selangor) Enactment 2003 (no. 2), Islamic Family law (Kelantan) Enactment 2002 (no.6), Islamic Family Law (Perlis) Enactment 1992 (no. 4), Islamic Family Law (Malacca) Enactment 2002 (no. 12).

${ }^{7}$ See Guardianship of Infants Act 1961, s. 3, Act 351.
} 
Islamic law. ${ }^{8}$ However, there are also provisions that are of general application, for example, the Child Act 2001 that provides inter alia that that Act shall apply throughout Malaysia, and there is no provision that states it does not apply to either Muslims or non-Muslims. ${ }^{9}$ Normally, it is indicated by the statute itself that the law is not applicable to Muslims, for example Adoption Act 1952 (the AA) provides that the AA shall not apply to any person professing the religion of Islam. ${ }^{10}$

In relation to the practice of Islamic law in Malaysia, it must be mentioned that the Islamic law in Malaysia is not purely based on the Shafi'i madhhab and in many occasions adopted the view of the Hanafi madhhab depending on the adaptability of the opinion to the society. This article deals with the application of fiqh al-Hanafi under the Islamic Family Law (Federal Territories) Act 1984. Analysis will extend to the practices in the Malaysian Syariah Court when dealing with cases involving Muslims and the most appropriate view of the madhhab that is to be adopted by the Syariah Court in order to solve a particular issue. The study employs the qualitative method of study where it only involves library research. It is believed that this research will be beneficial to all who seek knowledge and useful to all researchers, academicians, legal practitioners, students and scholars.

\section{ISLAMIC FAMILY LAW (FEDERAL TERRITORIES) ACT 1984}

In Malaysia, each state has its own enactment that governs family matters including matters relating to marriage and divorce, dower, duty to provide maintenance to wife and children, prohibited degrees of marriage, procedure of marriage, talaq, fasakh, khulu', ta'liq, iddah, ancillary rights, guardianship and custody of children. ${ }^{11}$ Those matters pertaining to the personal law of Muslims are governed and administered

\footnotetext{
${ }^{8}$ For example section 10 of GIA on removal of guardian is taken almost verbatim by the IFLA 1984, section 94.

${ }^{9}$ For example Child Act 2001 (Act 611), s. 1.

${ }^{10}$ For example Adoption Act 1952 (Act 257), s. 31.

11 See for example Islamic Family law (Selangor) Enactment 2003 (no. 2), Islamic Family law (Kelantan) Enactment 2002 (no.6), Islamic Family Law (Perlis) Enactment 2006 (no. 7), Islamic Family Law (Malacca) Enactment 2002 (no. 12).
} 
in the Syariah Court. Nevertheless, apart from the codified Islamic legislation, Islamic law in its original form is still referred to and applied as part of "Hukum Syarak". Hence, the term "Hukum Syarak" refers to Hukum Syarak (Islamic law) according to the Mazhab Shafie or according to one of the Mazhab Maliki, Hanafi or Hanbali. ${ }^{12}$ Accordingly, where the Islamic Act and Enactment is silent on or has not legislated that part of Islamic law, the court will then resort to Islamic law in its original form i.e. the "Hukum Syarak". ${ }^{13}$

In the Federal Territories, matters relating to Islamic Family Law are governed by the Islamic Family Law (Federal Territories) Act 1984 (the IFLA).${ }^{14}$ Although the law is only applicable to the Federal Territories of Kuala Lumpur, Labuan ${ }^{15}$ and Putrajaya, ${ }^{16}$ the provisions are not much different from the Islamic law enactments of other states. The IFLA can be considered as a model statute that provide uniformity of provisions governing Islamic Family Law applicable in all states in Malaysia. ${ }^{17}$ Many other State enactments follow the similar provisions as provided in the IFLA although it is contended that some states do not accept the law as many of its provisions are based on the Hanafi school of law while Malaysia commonly adopt positions under the Shafi'i school of law. ${ }^{18}$

12 See Islamic Family Law (Federal Territories) Act 1984, s. 2 (1). See also Islamic Family Law (Kelantan) Enactment 2002, (No. 6), s. 2(1), Islamic Family Law (state of Selangor) Enactment 2003 (No. 2), s. 2(1) and Islamic Family Law (Malacca) Enactment 2002 (No. 12), s. 2(1).

${ }^{13}$ See for example Islamic Family law (Federal Territories) Act 1984, s. 134A; Syariah Civil Procedure Code Enactment (Selangor), 1991, s. 253(2).

${ }^{14}$ Act 303.

${ }^{15}$ Islamic Family Law (Federal Territories) Act 1984, s. 2.

16 Putrajaya was inserted in the Federal Constitution of Malaysia as part of Federal Territories. See Federal Constitution, Ninth Schedule, State List, List II. See Constitutional (Amendment) Act 2001, (Act A 1095), s. 20(b). See also National Assembly Malaysian, Debate on suggestion that Putrajaya to be part of Federal Territory, Penyata Rasmi Dewan Rakyat, 2(60), Tenth Parliament, Second Session, Third Meeting, $6^{\text {th }}$ November 2000, DR 6.11.2000, no. 60, vol. 2, 26-28.

17 See Islamic Family Law (Federal Territories) Act 1984, The Annotated Statutes of Malaysia, Issue 2010, Lexis Nexis [hereinafter The Annotated Statutes of IFLA], 3.

${ }^{18}$ See Ahmad Ibrahim, Administration of Islamic law in Malaysia, 19. 
Furthermore, the IFLA is a Federal Islamic legislation. ${ }^{19}$ Therefore, for the purpose of the analysis on the application of fiqh al-Hanafi adopted by the Islamic Family Law Act and Enactments, the Islamic Family Law (Federal Territories) Act 1984 will be examined. This is important because it will provide alternatives in solving family issues in Malaysia. The analysis of the fiqh al-Hanafi will also be done in light of other provisions of Islamic Family law in other state enactments as well.

In principle, the IFLA is an Act endorsed by Seri Paduka Baginda Yang Di Pertuan Agong (YDPA) who is the Head of the Federation. It obtained the Royal assent on $27^{\text {th }}$ June 1984 and later, gazetted and published on $28^{\text {th }}$ June 1984 . It came into force on $29^{\text {th }}$ April $1987 .{ }^{20}$ It contains 135 sections altogether and 10 Parts or Chapters. Part I deals with Preliminary of the Act, Part II deals with marriage and its related subjects, Part III deals with Registration of Marriage, Part IV deals with Penalties and Miscellaneous Provisions Relating to the Solemnization and Registration of Marriage, Part V deals with Dissolution of Marriage and related subjects, Part VI deals with Maintenance of Wife, Children and others, Part VII deals with Guardianship and Custody, Part VIII deals with miscellaneous, Part IX deals with Penalties and Part X deals with general provisions. ${ }^{21}$

Notwithstanding the fact that Muslims in Malaysia are of Shafi'i madhhab and that Shafi'i madhhab is the official madhhab in Malaysia, the provisions of the IFLA recognizes and adopts all laws under the four Sunni schools i.e. the Hanafi, the Maliki, the Shafi'i and the Hanbali positions. This is manifested under the IFLA itself under the definition of "Hukum Syarak" i.e. a Malay Arabic word that is synonymous with the word Shari' ah or the phrase Islamic law..$^{22}$ It follows that there are quite a number of the provisions in the IFLA based upon fiqh al-Hanafi and conforms part of Malaysian law and governs the Muslims. Therefore, this paper wishes to examine those provisions of the IFLA that are based

\footnotetext{
19 See for example Islamic Family Law (State of Perak) Enactment 2004; Islamic Family Law (State of Perlis) 2006; Islamic Family Law (State of Kedah Darul Aman) 2008.

${ }^{20}$ See the Annotated Statutes of IFLA, 51-52.

${ }^{21}$ See Islamic Family Law (Federal Territories) Act 1984.

${ }^{22}$ See Islamic Family Law (Federal Territories) Act 1984, s. 2.
} 
upon fiqh al-Hanafi and the possible reasons why such provisions are adopted.

\section{APPRAISAL OF THE FIQH PROVISIONS BASED ON HANAFI SCHOOL OF LAW UNDER THE IFLA 1984}

As mentioned earlier, the IFLA contains the provisions based on the Shari'ah incorporating the view of the four Sunni schools of law. Apparently, there are several provisions that incorporate the view of the Hanafi school. The analysis is done chronologically from the beginning to the end of the statute.

\section{Minimum Age of Marriage}

In Malaysia, the minimum age of marriage for Muslim man and woman is provided in the IFLA that states among others;

"No marriage may be solemnized under this Act where either the man is under the age of eighteen or the woman is under the age of sixteen except where the Syariah judge has granted his permission in writing in certain circumstances." ${ }^{23}$

The minimum age of marriage of a man in the above provision is in line with the view of Imam Abu Hanifah as regards the age of puberty. He opined that the age of puberty of a boy if the natural symptom does not appear is eighteen years old and in a girl is seventeen years old. ${ }^{24}$ The Shafi'i jurists on the other hand regard that in the absence of natural symptoms, the age of puberty is fifteen years old in both boys and girls. ${ }^{25}$

\footnotetext{
${ }^{23}$ See Islamic Family Law (Federal Territories) Act 1984, s. 8.

${ }^{24}$ Al-Marghinani, Burhan al-Din Abi Hasan “Ali ibn Abi Bakr ibn 'Abd al-Jalil al-Rushdani, al-Hidayah Sharh Bidayat al-Mubtadi (Egypt: Mustafa al-Babi alHalabi, n.d), 3: 284; al-Zayla'i, Fakhruddin Uthman ibn 'Ali, Tabyin al-Haqaiq Sharh Kanz al-Daqaiq, ed. Al-Shaykh Ahmad 'Azw 'Inayah (Beirut: Dar alKitab al-'Ilmiyyah, 2000), 6:275-276. Nevertheless, it is said that the age of marriage of a girl that is sixteen years old also based on the view of Abi Hanifah. See the Annotated Statutes of IFLA, 106.

25 al-Sharbini, Syams al-Din Muhammad bin Ahmad, Mughni al-Muhtaj ila Ma'rifah Ma'ani Alfaz al-Minhaj, 1st ed. (Beirut: Dar al-Kutub al-Ilmiyyah, 1994), 2: 332.
} 
As regards minimum age of marriage of a female girl, the IFLA seems to provide an age below seventeen and above fifteen that is sixteen years old. It is said that this provision is in line with the age of puberty under the Hanafi school of law where there is no natural symptom appears. ${ }^{26}$ This seems to base on al-siyasah al-shar'iyyah ${ }^{27}$ by the Islamic legal authority in the administration of Islamic law in Malaysia.

The government has the authority to impose certain policy on minimum age of marriage based on the principle of 'taqyid al-mubah that is to limit what is permissible based on public interest (maslahah) to establish justice and not to prohibit what is permissible. According to Datuk Seri Dr Zulkifli Mohamad Al-Bakri, the Mufti of Federal Territories, ${ }^{28}$ the above policy is also followed by several Muslim majority countries like Jordan and Syria and is also supported by the prominent Muslim scholars like Syeikh Mustafa Siba'ie and Syeikh Dr Muhammad al-Zuhaily. Accordingly, to provide a minimum age of marriage is actually in line with the actual purpose of marriage ${ }^{29}$ In this situation, the adoption of the Hanafi position on the age of majority in IFLA is in line with public interest as well as the legal position adopted under civil laws in Malaysia, whereby the Age of Majority Act, 1971, which declares that a person becomes a major when he or she reaches the age of eighteen. Adoption of the Hanafi view and the issue of the determination of the age of majority relates closely to the issue of capacity to give consent to a marriage. This will be further discussed below.

\footnotetext{
${ }^{26}$ See the Annotated Statutes of IFLA, 106.

${ }^{27}$ Legal policy of an Islamic authority that refers to regulation issued by the Islamic Government in administration of justice.

${ }^{28} \mathrm{~A}$ mufti is the one who issues legal opinion (fatwa) relating to Islamic matters.

${ }^{29}$ See Fairul Asmaini Mohd Pilus, "Wajib patuhi undang-undang had umur minimum perkahwinan," $\quad B H \quad$ ONLINE, September 22, 2018, https://www.bharian.com.my/berita/nasional/2018/09/476808/wajib-patuhiundang-undang-had-umur-minimum-perkahwinan accessed 24 July 2019.
} 


\section{Consent Required in Marriage}

The IFLA requires consent of three people in the marriage of a woman, namely; the bride (virgin or non-virgin), the bridegroom and the wali. The IFLA states;

"A marriage shall not be recognized and shall not be registered under this Act unless both parties to the marriage have consented thereto, and either

a) the wali of the woman has consented thereto in accordance with Hukum Syarak; or

b) the Syariah Judge having jurisdiction in the place where the woman resides or any person generally or specially authorized in that behalf by the Syariah Judge has, after due inquiry in the presence of all parties concerned, granted his consent thereto as wali Raja in accordance with Hukum Syarak; such consent may be given wherever there is no wali by nasab in accordance with Hukum Syarak available to act or if the wali cannot be found or where the wali refuses consent without sufficient reason." 30

A bride's consent in marriage (where she is an adult woman) under the fiqh al-Hanafi is compulsory regardless of whether she is a virgin or non-virgin. ${ }^{31}$ Meanwhile, under the Shafi'i and jumhur ulama's view, only the consent of a non-virgin woman is compulsory. Nevertheless, the majority of Muslim jurists including the Shafi'i jurists opined that a father who is a wali mujbir may solemnize the marriage of his virgin daughter without her consent. ${ }^{32}$ It follows that regardless of the fact that majority of the Muslims in Malaysia are of Shafi'i madhhab and that even though the jumhur including the Shafi' $i$ jurists consider the consent of a wali is most important in a marriage of a daughter, the IFLA also requires the consent of the daughter (bride). This provision chooses to recognize the view of the Hanafis that requires woman's consent in marriage regardless of whether she is a virgin or non-virgin. This also seems to uphold an opinion that the role of a woman in her marriage is

\footnotetext{
30 See Islamic Family Law (Federal Territories) Act 1984, s. 13.

31 'Ala al-Din Abu Bakr ibn Mas'ud ibn Ahmad al-Kasani al-Hanafi, Badai' alSanai' fi Tartib al-Sharai', 1st ed. (Bayrut: Dar al-Kutub al-Ilmiyyah, 1996), 2: 360-362.

${ }^{32}$ See Al-Mawardi, Abu al-Hasan ubn Ali ibn Muhammad ibn Muhammad ibn Habib al-Basri, al-Hawi al-Kabir fi Fiqh Madhhab al-Imam al-Shafi' $i$, Sharh Mukhtasar al-Muzani (Bayrut: Dar al-Kutub al-Ilmiyyah, 1999), 9: 38.
} 
not lesser than that of a wali. It is after all her marriage and acknowledging her consent shows that the woman's right to choose her life partner is recognized under the Shari' ah. Furthermore, this provision is in line with the law in several Muslim Countries like Jordan and Morocco. ${ }^{33}$ As such, the Hanafi approach to the issue could be seen as giving recognition to the consent that needs to be obtained from a woman once she has reached the age of majority, whether or not she is a virgin.

The next part of the article highlights the issue of betrothal or agreement to marry and how the adoption of the Hanafi view has affected the application of the law under the Act.

\section{Betrothal or Agreement to Marry}

Betrothal can generally be understood as a proposal or an agreement to marry between man and woman in accordance with Islamic law. The IFLA has one provision for betrothal, especially to provide a remedy to the non-defaulting party in the event of a breach of promise to marry. The IFLA provides;

"If any person has either orally or in writing, and either personally or through an intermediary, entered into a betrothal in accordance with Hukum Syarak, and subsequently refuses without lawful reason to marry the other party, the other party being willing to marry, the party in default shall be liable to return the betrothal gifts, if any, or the value thereof and to pay whatever moneys have been expended in good faith by or for the other party in preparation for the marriage, and the same may be recovered by action in the Court" ${ }^{\prime 34}$

Basically the above provision seems to be based on the view of the Maliki jurists that state among others, that if the breach of betrothal is from the man, he has no right to take back the gifts given and if the breach comes from the woman, then the man will have the right to take

\footnotetext{
${ }^{33}$ See Azizah Mohd, Badruddin $\mathrm{Hj}$ Ibrahim and Syafiqah Abd Razak, "Protecting Women's Interest (Maslahah) in Marriage through Appointment of a Guardian (Wali) under Islamic Law," E-PROCEEDINGS OF THE 4TH INTERNATIONAL CONFERENCE ON LAW AND SOCIETY 2015 (ICLAS IV), UNISZA, 10-11 May 2015, 298.

${ }^{34}$ Islamic Family Law (Federal Territories) Act 1984, s. 15.
} 
back the gifts given by him. ${ }^{35}$ This indicates that, the party who is not at fault will have the right to claim for any gifts given during the betrothal ceremony. However, the IFLA could be said to also incorporate the view of the Hanafi jurists, to a certain extent. As regards the fiqh al-Hanafi, the position is similar in that, in the event of breach, the betrothal gifts should be returned if the gifts still exist and are not destroyed based on the rules of gift (hibah) ${ }^{36}$ In the case where the gifts are no longer in existence, the IFLA corresponds with the view of the Maliki jurists that the value should be returned. ${ }^{37}$

It is interesting to note that, Section 15 of the IFLA also highlights on remedy for 'whatever moneys have been expended in good faith by or for the other party in preparation for the marriage'. This provision seems to also be in line with the view of the Maliki jurists. ${ }^{38}$

It is now necessary to look at the influence of the Hanafi position on matters relating to divorce.

\section{Divorce by Talaq or by Order}

Talaq generally means the dissolution of a valid marriage. Talaq is an Arabic word, the verb of which is 'tallaqa' (past tense) and 'yutalliqu' (present tense). ${ }^{39}$ According to al-Zuhayli, talaq literally means untying the marriage knot. Technically, talaq means untying the marriage contract (' $a q a d$ ) by using the word talaq and others. ${ }^{40}$ In Malaysia, the husband or the wife who desires a divorce may file an application to dissolve his/her marriage through the pronouncement of talaq. ${ }^{41}$ If the

\footnotetext{
${ }^{35}$ See 'Abd al-Karim Zaydan. Al-Mufassal fi Ahkam al-Mar'ah wa al-Bayt alMuslim fi al-Shari'ah al-Islamiyyah, 4th ed. (Beirut Lebanon: Muassasat alRisalat, 2012/1433), 6: 74-75.

36 Ibid., 75.

${ }^{37}$ Ibid., $75-78$.

${ }^{38}$ See Wahbah al-Zuhayli, al-Fiqh al-Islami wa adillatuhu, (tr), Vol. 7.

39 Zayn al-'Abidin Muhammad ibn Abi Bakr ibn 'Abd al-Qadir al-Hanafi alRazi, Mukhtar al-Sohhah (Beirut: al-Maktabah al-'Asriyyah, 1999), 192.

${ }^{40}$ Wahbah al-Zuhayli, al-Fiqh al-Islami wa Adillatuhu, 12th ed. (Damsyik: Dar al-Fikr, n.d), 9: 6873.

${ }^{41}$ See Islamic Family Law (Federal Territories) Act 1984, s. 47(1).
} 
parties mutually agree to the divorce, the Court will order the husband to pronounce one talaq in the Court. The IFLA provides to the effect;

"If the other party consents to the divorce and the Court is satisfied after due enquiry and investigation that the marriage has irretrievably broken down, the Court shall advise the husband to pronounce one talaq before the Court". ${ }^{42}$

The above provision provides for the best form of talaq to be pronounced by the husband upon agreement by both parties. This is advisable as Islamic law enjoins divorce in kindness. ${ }^{43}$ This is in line with both views of Hanafi and Shafi'i jurists and is also prescribed by all Sunni schools of law. ${ }^{44}$ The IFLA further provides for the effect of such kind of talaq that operates to dissolve the marriage after the expiry of the period of 'iddah as it is a revocable talaq (talaq raj'ie). ${ }^{45}$

Pronouncement of a divorce may also lead to the claim for the custody of children. This will be explained in the next part of this article.

\section{Duration of Custody}

The IFLA also provides on custodial right of a child especially in the case of divorce. As regards to the duration of custody, the Shafi'i jurists did not differentiate duration for the custody of a male and female child, i.e. until the child attains the age of seven years. ${ }^{46}$ Nevertheless, the IFLA in section 84 , adopts the view of the Hanafi ${ }^{47}$ position and provides that;

"The right of hadinah to the custody of a child terminates upon the child attaining the age of seven years in the case of a male, and the age of nine years in the case of a female..."

\footnotetext{
${ }^{42}$ See Islamic Family Law (Federal Territories) Act 1984, s. 47(3).

${ }^{43}$ See the Qur'ān, 2: 229.

${ }^{44}$ See for example Al-Kasani, 'Ali' al-Din Abi Bakr ibn Mas'ud, Bada'i ‘ alsana ' $i$ ' fi tartib al-Shara 'i’ (Beirut: Dar al-Fikr, 1996/1417), 3: 129.

${ }^{45}$ See Islamic Family Law (Federal Territories) Act 1983, s. 47(16).

${ }^{46}$ See Mustafa al-Khin et al., al-Fiqh al-Manhaji 'Ala Madhhab al-Imam alShafi'i (Damshiq: Dar al-Qalam, 2000), 2: 183.

${ }^{47}$ See Hafiz al-Din al-Nasfi, Abi al-Barakat 'Abdullah bin Ahmad bin Mahmud, al-Bahr al-Ra'iq Sharh Kanz al-Daqaiq (fi al-Furu' alHanafiyyah) (Beirut: Dar al-Kutub al-'Ilmiyyah, n.d.), 4: 287-288.
} 
The Hanafi jurists have differentiated the duration of a male and female child in the determination of a child's custody. It is submitted that this seems to be more practical and adaptable to the Malaysian situation, where the love, affection and attention of a mother should be the determining factor when deciding the custody of boys before they reach seven years old and nine years old for a girl. It could be argued that a female child needs to stay with the mother longer due to the fact that she may need to learn and experience about being a wife and learn a mother's role by being with her mother. Furthermore, she needs her mother to guide her when she approaches the age of puberty. The principle on the duration of custody based on figh al-Hanafi was also directly applied in the Syariah Courts in Malaysia, for example, in the case of Wan Abdul Aziz v Siti Aishah, ${ }^{48}$ the father applied for the custody of his daughter aged nine years old, who at the material time, stayed with the mother. In that case, the mother had remarried. Despite that fact, the Trial Court held that it was for the welfare of the child to remain with the mother and maternal grandmother. Furthermore, the girl herself chose to live with the mother and maternal grandmother. This case reflects the adoption of the Hanafi position, where the custody was determined based on the age of the child, whereby she was still nine years old at the time of the proceeding.

Aside from the issue of the determination of custody, another aspect of the fiqh al-Hanafi that can be said to be present in the IFLA is in situations relating to the ascription of paternity, which is discussed below.

\section{Ascription of Paternity}

The IFLA provides for ascription of paternity in cases where a child is born six months from the date of the marriage. This is unanimously agreed by the four Sunni schools including the Hanafi jurists, whereby the child will be legitimate and is ascribed to the father. ${ }^{49}$ The IFLA states;

48 (1975) $1 \mathrm{JH}(1)$.

49 Muhammad Abu Zahrah, al-Ahwal al-Shakhsiyyah (N.p.: Dar al-Fikr al'Arabi, 1957), 387. 
"Where a child is born to a woman who is married to a man more than six qamariah months from the date of the marriage or within four qamariah years after dissolution of the marriage..."50

In principle, the above provision is basically based on the view of the majority including the Shafi'i school. However, the Hanafi jurists share the same opinion on the shortest term of pregnancy that is six months after the date of marriage. ${ }^{51}$ As for the maximum period of pregnancy, Muslim jurists differ. Imam Malik's view is that the longest period of pregnancy is five years. While according to Imam Shafi' $i$, it is four years and this is also the view of most Maliki and Hanbali jurists. The rationale of this argument is basically the existence of such pregnancy during those periods and based on a report by Dar al-Qutni that Imam Malik said our neighbor, the wife of Muhammad bin Ajlan got pregnant three times for twelve years. While Imam Shafi'i stated that Muhammad bin Ajlan was delivered after four years conception while Imam Ahmad said that the women from Bani Ajlan had conceived for four years. ${ }^{52}$ On the other hand, the Hanafis opined that the longest period of pregnancy is two years. And this is also the view of Imam Ahmad ibn Hanbal. They based this upon a narration from 'Aishah (ra) where she said that the pregnancy period of a woman cannot be more than two years. Other views are from the Maliki jurist Muhammad ibn al-Hakam who said that the maximum period of pregnancy is one year, while the Zahiri school of law ${ }^{53}$ said that

${ }^{50}$ See Islamic Family Law (Federal Territories) Act 1984, s. 110.

51 This is based on the Qur'ān, 46:15; Qur'ān, 31:14; Qur'ān, 2:233. The Muslim jurists had concluded that the minimum term of pregnancy, based on the above verses, is six months after 30 months (the period of gestation and weaning) in the first verse by deducting the 24 months given (the period of weaning) in the second verse. Other than this verse, they also refer to a narration on the practice of the companions during the period of 'Umar al-Khattab where a woman gave birth to a baby after six months pregnancy. "Umar wished to impose hadd punishment on the woman but this was objected to by 'Ali ibn Abi Talib who recited the above Surah al-Baqarah and Surah Luqman. With that, 'Umar al-Khattab discontinued the punishment. See Muhammad Abu Zahrah, al-Ahwal al-Shakhsiyyah, 386.

${ }^{52}$ See 'Abdul Karim Zaydan, al-Mufassal fi al-Ahkam al-Mar'ah wa al-Bayt alMuslim fi al-Shari'ah al-Islamiyyah, Vol. 9, (Beirut Lebanon: Muassasah alRisalah, 2012), 346-347.

${ }^{53}$ Zahiri school is founded by Daud Ibn 'Ali al-Isfahani, better known as Abu Sulayman al-Zahiri, and is one of the extinct Sunni schools of law which no 
it is nine months, ${ }^{54}$ as it is common in a society that a woman may deliver after nine months to one-year pregnancy. ${ }^{55}$

There are several cases involving claim of paternity of a child, all of which deal with the claim of maintenance on a child born within a certain period which raised doubts about the legitimacy. In the case of Wan Azmi $v$ Nik Salwani ${ }^{56}$ a child was born after more than eight months of marriage between the plaintiff and the defendant, the Court held that the child is legitimate based on the proof that there was intercourse between the plaintiff and the defendant and the child was born after eight months and fourteen days from the date of the intercourse. In the case of Norzaini binti Alias $v$ Mohamad Sharif bin Mohamad Taib, ${ }^{57}$ the plaintiff applied for maintenance for her 13-year-old child, but the father denied that the child was his. The Court held that the child is legitimate and ascribed to the father as the child was born after ten and a half months from the date of the marriage and there was intercourse between the plaintiff and the defendant after their marriage.

In the case of Wan Khairil bin Wan Azmi v Farah Nurliliana bt Jauhari, ${ }^{58}$ the applicant made an application to declare that a baby boy who was born to the respondent on 7 December 2010, is the legitimate child of both parties in accordance to the Hukum Syarak and thereafter, to ascribe paternity of the child to the applicant. The applicant and respondent were married on 9 Jun 2010 with the respondent's father as her wali. The marriage was registered by the Registrar of Muslim Marriage, Divorce and Ruju', Besut. After the marriage, both applicant and respondent were living together as husband and wife and never divorced. The court held that the applicant's application to ascribe

longer exist. The school was known as al-Zahiri because he abided by the literal texts of the Quran and the Sunnah. However, their rulings and opinions may be applicable in certain cases. See S. Mahmassani, Falsafah al-Tashri'fi al-Islam, trans. Farhat J. Ziadeh (Malaysia: Hizbi, 1981), 34.

${ }^{54}$ See Muhammad Abu Zahrah, al-Ahwal al-Shakhsiyyah, 386-387. For further reading see also Najibah Mohd Zin et al., Islamic Family Law in Malaysia (Kuala Lumpur: Thomson Reuters Malaysia Sdn Bhd, 2016), 299 - 301.

${ }^{55}$ See 'Abdul Karim Zaydan, 346.

56 [1990] 9 JH (2) 192. See also Salim v Masiah [1976] 2 JH (2) 296; Hj

Ghazali v Asmah (1977) $1 \mathrm{JH} 81$.

57 (2003) $16 \mathrm{JH}$ (2) 101.

58 [2011] 2 SHLR 1. 
paternity of the child to him was allowed as the conditions of legitimacy of a child were based on the enacted law and the Hukum Syarak. In this case the child was born more than 6 months after the marriage and during the six months period of pregnancy, they were living as husband and wife during their marriage and the husband was also able to consummate the marriage.

These decided cases show that the application of section 110 of the IFLA has adopted the view of the jumhur al-fuqaha' including the Hanafi view and this allows the courts to consider the minimum requirement (6 months) in order to ascribe paternity to a man as the father of the child.

From here, an analysis of the evidentiary requirements in IFLA that adopt the Hanafi position needs to also be done as it related to proving legitimacy of a child under section 110 of IFLA. This is dealt with in the next part of this article.

\section{Acknowledgement (al-Iqrar) and Conditions for a Valid Acknowledgement}

Based on the above discussion and the earlier provision in section 110 of IFLA, a child can only be ascribed to the biological father if he is born after six months from the date of marriage of his mother and biological father. The question that might arise here is whether a child who is born less than six months from the date of marriage can be legitimized.

The IFLA further provides for means of legitimation of a child whose status is unknown or deems to be illegitimate through acknowledgement (al-iqrar). The IFLA provides among others;

"Where a man acknowledges another, either expressly or impliedly, as his lawful child, the paternity of the child shall be established in the man if the following conditions are fulfilled, that is to say;

a) the paternity of the child is not established in anyone else;

b) the ages of the man and the child are such that filial relationship is possible between them;

c) where the child is of discreet age, the child has acquiesced in the acknowledgement; 
d) the man and the mother of the child could have been lawfully joined in marriage at the time of conception;

e) the acknowledgement is not merely that he or she is his son, but that the child is his legitimate son;

f) the man is competent to make a contract;

g) the acknowledgement is with distinct intention of conferring the status of legitimacy;

h) the acknowledgement is definite and the child is acknowledged to be the child of his body." 59

The above provisions are also based on fiqh al-Hanafi. ${ }^{60}$ It does not stipulate that the child must not be born less than six months in a marital relationship. It seems that the Hanafi school of law is more lenient in conferring the status of legitimacy. Abd Karim Zaydan in his book highlighted the view of the Hanafis based on the book of Fatawa alHindiyyah; it is stated that if a child is born less than six months from the date of the marriage, he is illegitimate unless the father acknowledges that the child is his legitimate child. ${ }^{61}$ Therefore, regardless of whether the child is of unknown status or is the product of adultery before marriage but is born after marriage, the biological father may ascribe the child's paternity to him through acknowledgement. The IFLA in the above provisions seems to agree with this for the purpose of protecting the interest of a child who is in need of a father. ${ }^{62}$

Recently, there was one case in the Syariah Court where a child was held to be legitimate based on silent acknowledgement. It was in the case of Zafrin Zulhilmi bin Pauzi v Noor Aini bt Nasron, ${ }^{63}$ where the applicant

\footnotetext{
${ }^{59}$ See Islamic Family Law (Federal Territories) Act 1984, s. 114.

${ }^{60}$ This is also the view of Hasan al Basri, Ibn Sirin, Ishak, Urwah ibn Zubir, Sulaiman ibn Yassar and Ibn Taimiyyah. See 'Abd Karim Zaydan, Al-Mufassal Fi Ahkam al-Mar'ah wa al-Bayt al-Muslim Fi al-Syari'ah al-Islamiyyah (N.p.: Muassasah al-Risalah, n.d) 9: 382-383.

61 'Abd Karim Zaydan, Al-Mufassal Fi Ahkam, 9: 383.

${ }^{62}$ Muhammad ibn al-Salih, al-Tifl Fi al-Shari'ah al-Islamiyyah (N.p.: n.p., n.d.), 80-81. See also 'Ala al-Din Abu al-Hasan 'Ali Muhammad ibn 'Abbas alBa'li, "Al-Ikhtiyarat al-Fiqhiyyah Min Fatawa Shaykh al-Islam Ibn Taimiyyah" (Egypt: Maktabah al-Sunnah al-Muhammadiyyah, n.d), 283.

${ }^{63}$ [2013] 2 ShLR 39.
} 
sought for an order that a baby girl, Nur Damia Aqilla bt Abdullah, is the legitimate child of the respondent, Noor Aini bt Nasron and the applicant, Zafrin Zulhilmi bin Pauzi, in accordance with Hukum Syarak. The baby was born on 3 September 2010 while the marriage between the applicant and respondent was solemnized on 16 April 2010. It was only 4 months and 24 days from the date of the marriage till the day that the baby was born. Both parties had lived together as husband and wife after their marriage without being divorced.

The application was also supported by the respondent. The court held that the applicant could ascribe paternity of the child to him. The court in this case was satisfied that the marriage between the applicant and respondent was solemnized in accordance with Islamic law on 16 April 2010 with the respondent's father as her wali. Besides, the court held that the period of 4 months and 24 days between the date of the marriage and the date of the child was born was not adequate to ascribe paternity of the child to the applicant. This is because the Islamic law requires for at least 6 months before a child can be attributed to the father.

The court further held that the paternity of the child is ascribed to the applicant according to the enacted laws and its regulations. The applicant did not mention that the child was conceived out of wedlock when he was requesting to ascribe paternity to the child. The court also held that a 'legitimate child according to the enacted laws and its regulation' means that the child is a legitimate child to the applicant in all matters except on the guardianship and inheritance matters. Though the child is considered as a legitimate child to the applicant, he cannot be the child's guardian (wali) and both of them cannot inherit from each other.

The court in this case was also satisfied that the baby girl, who was born to the respondent on 3 September 2010, Nur Damia Aqilla bt Abdullah, was that of the applicant based on the provisions of Hukum Syarak. Consequently, the Registrar of Births and Deaths Terengganu shall register the child. The applicant and respondent must take attention and never forget that the applicant could not be the child's wali. At the same time, the child and the applicant could not inherit from each other. ${ }^{64}$

${ }^{64}$ See also Najibah Mohd Zin et al., Islamic Family Law, 312-314. 


\section{CONCLUSION}

Islamic law consists of a comprehensive legal system and is applicable to all. It is adaptable to any situation and is flexible in the sense that the change of time and circumstances may result in the change of certain rules in the spirit of the Shari'ah i.e. based on public interest.

The main sources of Islamic law are ultimately the Quran and the Sunnah of the Prophet (saw). Due to different interpretation of the texts in the Quran and Sunnah, Muslim jurists differ in their views but never contradict any text and had always been in line with the general spirit and maqasid al-Shari'ah. The different views of the jurists are a blessing as it may accommodate many groups of people who might subject to a different custom and usage as well as different problems and circumstances.

Problems and practices might vary from time to time and between localities. In this regard, juristic views play an important role to complement one another. Malaysian government may serve as example for an Islamic country whose madhhab is Shafi'i but to a certain extent follows and adopts the views of other jurists including the Hanafis to make it compatible to Malaysian people, locality, custom and environment. This also reflects the universality and flexibility of Islamic religion especially in safeguarding the interest of the public. 